\title{
Utjecaj Europskog semestra na proračunski proces u Hrvatskoj
}

\author{
KATARINA OTT Institut za javne financije
}

Iz godine u godinu, Ministarstvu financija i vladama se opravdano prigovara zbog nepridržavanja rokova, nerealističnih pretpostavki i neadekvatnog sadržaja ključnih dokumenata (strateški planovi, strategije $i$ smjernice) koji služe za pripremu trogodišnjeg proračuna. Te manjkavosti dovode do čestih rebalansa proračuna i nezadovoljavajućih fiskalnih rezultata. Kako će ulazak Hrvatske u EU utjecati na ekonomsku politiku i javne financije u Hrvatskoj? Kako će se odraziti na proračunski proces - od strategije, smjernica, do plana proračuna? Što će se točno događati kad uđemo u EU? Što se već počelo događati?

\section{EUROPSKI SEMESTAR}

Ekonomska kriza ukazala je na potrebu snažnije koordinacije ekonomskih politika članica EU-a, usklađivanja procesa i ciljeva nacionalnih proračunskih politika i politika rasta i zapošljavanja. Zbog toga na razini EU-a od 20II. djeluje tzv. Europski semestar (sažeto prikazan u tablici r) koji se tako zove jer se glavnina ciklusa koordinacije odvija u prvih šest mjeseci svake godine. Članice usklađuju proračunske i ekonomske politike s ciljevima i pravilima dogovorenim na razini EU-a kako bi osigurale zdrave javne financije, potakle ekonomski rast i spriječile pretjerane makroekonomske neravnoteže. Po utvrđenom kalendaru primaju upute na temelju kojih podnose nacionalne programe koji se ocjenjuju na razini EU-a. Nakon ocjene nacionalnih programa, članice dobivaju individualne preporuke za nacionalne politike proračuna i reformi. Ako je potrebno dobivaju i preporuke za ispravljanje makroekonomskih neravnoteža. Cilj je da članice uzmu u obzir preporuke kad definiraju proračune za iduću godinu.

Novi ciklus Europskog semestra otpočinje ponovo krajem godine, kad Europska komisija objavljuje Godišnji izvještaj o rastu s pregledom ekonomske situacije i ocjenom napretka svake članice u primjeni preporuka iz prošlogodišnjeg Semestra. 
Tablica I.

Europski semestar

\begin{tabular}{l}
\hline Pripremna faza \\
Studeni i prosinac \\
\hline
\end{tabular}

Objavljuje Godišnji izvještaj o rastu (Annual Growth Survey), s prioritetima za iduću godinu koje članice trebaju uzeti u obzir pri planiranju nacionalne ekonomske politike, te Izvještaj o znakovima na uzbunu Europska komisija (Alert Mechanism Report) o makroekonomskoj situaciji pojedinih članica, na temelju kojeg može odlučiti hoće li provesti detaljniji pregled situacije u članicama u kojima se rizik potencijalnih makroekonomskih neravnoteža čini visokim, a na temelju njih i preporuke članicama.

\begin{tabular}{ll}
\hline Prva faza: Usmjeravanje politika na razini EU-a \\
\hline Siječanj i veljača & Raspravlja o Godišnjem izvještaju o rastu i daje mišljenje i preporuke. \\
\hline Vijeće EU-a & $\begin{array}{l}\text { Raspravlja o Godišnjem izvještaju o rastu i daje mišljenja i preporuke, te daje mišljenje o Smjernicama } \\
\text { za zaposlenost (Employment Guidelines), a može pozvati i predstavnike Vijeća EU-a, Europskog vijeća, } \\
\text { Komisije i pojedinačnih zemalja članica na raspravu o temama vezanim uz Europski semestar. }\end{array}$
\end{tabular}

\begin{tabular}{ll}
\hline Ožujak & $\begin{array}{l}\text { Na temelju Godišnjeg izvještaja o rastu, te analiza i zaključaka Vijeća EU-a, predstavlja smjerove } \\
\text { politike. Od članica zahtijeva da ih uzmu u obzir u pripremi nacionalnih programa stabilnosti ili } \\
\text { konvergencije koji zacrtavaju nacionalne proračunske politike i politike poticanja rasta i } \\
\text { konkurentnosti. }\end{array}$ \\
\hline
\end{tabular}

Europska komisija Objavljuje temeljite preglede makroekonomskih neravnoteža provedenih u visokorizičnim članicama, na temelju kojih može dati preporuke članicama za njihovo ispravljanje.

Druga faza: Ciljevi, politike i planovi za pojedinačne članice

Travanj

Do I5-og, a najkasnije do 30-og travnja podnose nacionalne programe stabilnosti i konvergencije sa srednjoročnim proračunskim strategijama i nacionalnim programima reformi s planovima strukturnih reformi za poticanje rasta i zaposlenosti.

\begin{tabular}{ll}
\hline Svibanj & \\
\hline Europska komisija & Ocjenjuje nacionalne planove zemalja članica i daje nacrt preporuka svakoj pojedinoj članici. \\
\hline Lipanj & $\begin{array}{l}\text { Raspravlja o nacrtima preporuka zemljama članicama i dogovara konačne preporuke za svaku } \\
\text { pojedinu članicu koje mora podržati Europsko vijeće. }\end{array}$ \\
\hline Vijeće EU-a & Usvaja preporuke za svaku pojedinačnu članicu od kojih očekuje da ih i primjenjuje. \\
\hline Srpanj & \\
\hline Vijeće EU-a & $\begin{array}{l}\text { Uzimaju u obzir preporuke u procesu nacionalnog odlučivanja o nacionalnom proračunu za iduću } \\
\text { godinu koji će im omogućiti da provedu zacrtane politike. }\end{array}$ \\
\hline Treća faza: Primjena &
\end{tabular}




\section{ProračUnSKI PROGES U HRVATSKOJ}

Tablica 2 prikazuje hrvatski proračunski proces u prvoj polovici godine.

Tablica 2.

Hrvatski proračunski proces u prvoj polovici godine

\begin{tabular}{|c|c|}
\hline \multicolumn{2}{|l|}{ Do sredine ožujka } \\
\hline $\begin{array}{l}\text { Ministarstvo financija u suradnji } \\
\text { s Ministarstvom regionalnog razvoja } \\
\text { i fondova EU-a }\end{array}$ & $\begin{array}{l}\text { Ministarstvima i drugim državnim tijelima dostavlja uputu za izradu strateških } \\
\text { planova za trogodišnje razdoblje. }\end{array}$ \\
\hline \multicolumn{2}{|l|}{ Do sredine travnja } \\
\hline ministarstva i druga državna tijela & $\begin{array}{l}\text { Ministarstvu financija dostavljaju vlastite strateške planove za trogodišnje } \\
\text { razdoblje. }\end{array}$ \\
\hline \multicolumn{2}{|l|}{ Do kraja travnja } \\
\hline $\begin{array}{l}\text { Ministarstvo financija i Ministarstvo } \\
\text { regionalnog razvoja i fondova EU-a }\end{array}$ & Vladi predlažu strategiju za trogodišnje razdoblje. \\
\hline \multicolumn{2}{|l|}{ Do sredine svibnja } \\
\hline Vlada & Donosi trogodišnju strategiju. \\
\hline \multicolumn{2}{|l|}{ Do kraja svibnja } \\
\hline Ministarstvo financija & Vladi predlaže smjernice ekonomske i fiskalne politike. \\
\hline \multicolumn{2}{|l|}{ Do sredine lipnja } \\
\hline Vlada & Donosi smjernice ekonomske i fiskalne politike. \\
\hline \multicolumn{2}{|l|}{ Do kraja lipnja } \\
\hline Ministarstvo financija & $\begin{array}{l}\text { Dostavlja ministarstvima i drugim državnim tijelima na razini razdjela } \\
\text { organizacijske klasifikacije i izvanproračunskim korisnicima upute za izradu } \\
\text { prijedloga državnog proračuna. }\end{array}$ \\
\hline
\end{tabular}

Upute za izradu strateških planova za trogodišnje razdoblje, koje su do sredine ožujka trebale biti poslane ministarstvima i drugim državnim tijelima, na web stranici Ministarstva financija objavljene su tek krajem travnja. Kašnjenje je uobičajeno - prošle je godine, umjesto do sredine ožujka to učinjeno u travnju - pa su i iduće faze kasnile. Trogodišnju strategiju, koju mora donijeti do sredine svibnja, Vlada je donijela tek sredinom srpnja, a smjernice ekonomske i fiskalne politike umjesto do sredine lipnja, tek u kolovozu. Posljedično su kasnile i upute, prijedlozi, nacrti i konačno usvajanje proračuna. Prošla godina nije nikakva iznimka; bilo je godina kada su kašnjenja bila i znatno duža.

No, kašnjenja u fazama hrvatskog proračunskog procesa i nisu njegova najveća boljka. Ozbiljniji problem su manjkave i, na neadekvatnim makroekonomskim pretpostavkama utemeljene strategije i planovi, te slaba provedba planiranog, iza čega slijede česti rebalansi i konstantno loši makroekonomski rezultati.

\section{UTJEGAJ EUROPSKOG SEMESTRA NA PRORAČUNSKI PROGES U HRVATSKOJ}

Ulaskom Hrvatske u EU, pa time i u Europski semestar, dolazi do ključnih promjena:

- Ministarstvo financija će se pri sastavljanju upute ministarstvima i drugim državnim tijelima za izradu strateških planova - koje donosi do sredine ožujka - morati oslanjati na prioritete zacrtane u Godišnjem izvještaju o rastu, Izvještaju o znakovima na uzbunu i Smjernicama za zaposlenost. Ti su dokumenti u razdoblju od studenoga prošle, do veljače tekuće godine, prošli Europsku komisiju, Vijeće EU-a i Europski parlament. 
- Kako bi do I5-og, a najkasnije do 30-og travnja EU-u dostavila nacionalni program stabilnosti i konvergencije sa srednjoročnom proračunskom strategijom i programom reformi s planom strukturnih reformi usmjerenih na poticanje rasta i zaposlenosti, Vlada će trogodišnju strategiju, koju za domaće potrebe mora donijeti do sredine svibnja, sada morati sastaviti mjesec dana ranije.

- Europska komisija će u svibnju ocijeniti hrvatski nacionalni plan i dati konkretne preporuke za njegovo poboljšanje, pa će Ministarstvo financija te preporuke moći ugraditi u prijedlog smjernica ekonomske i fiskalne politike koji do kraja svibnja mora predložiti Vladi.

- Vlada će do sredine lipnja moći donijeti kvalitetne smjernice ekonomske i fiskalne politike koje će uvažavati ocjene i preporuke Europske komisije iz svibnja, te Vijeća EU-a iz lipnja.

- Vijeće EU-a u srpnju usvaja konačne preporuke za svaku pojedinačnu članicu, a od članica se očekuje da ih primjenjuju. Stoga će i Hrvatska - kao i sve druge članice - u srpnju, pri uputama za izradu i samoj izradi prijedloga proračuna, morati uzeti u obzir preporuke Vijeća EU-a, neophodne za provedbu zacrtane politike.

Ulazak Hrvatske u EU i Europski semestar sasvim će sigurno utjecati na rokove i kvalitetu, pa time i na transparentnost strategija, planova i proračuna u Hrvatskoj. Pozitivan utjecaj tih promjena neće, naravno, ovisiti samo o europskim institucijama i procesima, već i o zainteresiranosti i angažmanu hrvatskih ministarstava i Vlade za praćenje i razumijevanje funkcioniranja europskih institucija i procesa, te pravovremeno ugrađivanje europskih uputa i preporuka u hrvatske dokumente.

Već i prije formalnog članstva, Europska je komisija pozvala Hrvatsku da se neformalno uključi u Europski semestar, pa je Vlada I8. travnja prihvatila Ekonomski program Republike Hrvatske 20I3. koji će dostaviti Europskoj komisiji. Ne ulazeći u detaljnu analizu Programa, već je na prvu očito da je - kao i gotovo svi dosadašnji hrvatski dokumenti - rađen na preoptimističnim pretpostavkama. Vlada $u$ Programu predviđa rast BDP-a od 0,7\% 2013. i 2,4\% 20I4., dok nam Europska komisija predviđa pad od 0,4\% 2OI3. i rast od samo I\% 20I4., a Međunarodni monetarni fond pad od o,2\% 2OI3. i rast od I,5\% 2 OI4.

Otpočeli smo, dakle, s preoptimističnim pretpostavkama koje ne uzimaju u obzir čak ni predviđanja hrvatskog gospodarskog rasta te iste Europske komisije kojoj program šaljemo. Vidjet ćemo, stoga, kako će Program biti ocijenjen i kakve će nam preporuke na temelju njega dati Europska komisija, Vijeće EU-a i Europsko vijeće. Shvatimo li te preporuke ove godine olako - u Europski semestar smo uključeni tek neformalno - u idućim godinama to neće biti moguće, jer se od članica očekuje da preporuke i primjenjuju. Budući da je dosljedna primjena preporuka neophodni preduvjet za davanje financijske pomoći članicama koje zbog previsokog deficita i duga ostvaruju to pravo - a Hrvatska već sada zadovoljava uvjete za primanje te pomoći - valjda će to biti dovoljan motiv za dosljednu primjenu. No, barem smo otpočeli, pa se u idućim godinama valja nadati realističnijim, pravovremenijim i kvalitetnijim strategijama, planovima, programima i proračunima, te dosljednoj primjeni europskih preporuka. Time bismo postali i zemlja s dugoročno zdravijim i transparentnijim javnim financijama. 